\title{
Beauty Italian Style: Gendered imaginings of, and responses to stage divas in early post-Unification literary culture*
}

\section{Katharine Mitchell}

\section{University of Strathclyde, Glasgow}

In this article I argue that Bartky's 'fashion-beauty complex' - a major articulation of capitalist patriarchy which seeks to glorify the female body, yet covertly depreciates it - gained momentum in Italian culture at the end of the nineteenth century through the emergence of the cosmetic industry and divas' advertising of beauty products in women's magazines. Through a close reading of the literary culture (reviews of divas' performances in women's and theatre journals, as well as realist fiction), I show that the discursive construction of the Italian diva in this period was gendered: though women writers demonstrate an awareness of, and take pleasure in the diva's 'beauty', but above all celebrate her skills and talents as a performing artist, male writers without exception - pass comment on the diva's appearance over and above a critique of her performing skills. This would suggest that 'the beauty myth' - the idea that a woman's value is determined by her appearance - was an integral component of divadom in late nineteenth-century Italy, and, for male journalists and writers, an even more important attribute than the diva's acting or singing abilities.

Keywords: 'fashion-beauty complex', women writers, to-be-looked-at-ness, cosmetics industry, definitions of the diva, feminine beauty

In La Marchesa Colombi's domestic novel Un matrimonio in provincia (1885), the middle-class protagonist, Denza, aged sixteen, is told that she is 'beautiful' by her stepmother. This prompts Denza to contemplate herself undoing her plaits in front of the mirror each night before going to bed. ${ }^{1}$ Denza's auto-eroticism and narcissism arguably facilitates her participation in what Sandra Lee Bartky has termed the 'fashion-beauty complex', which she defines as:

a major articulation of capitalist patriarchy [...] a vast system of corporations - some of which manufacture products, others services and still others information, images and ideologies - of emblematic public personages and of sets of techniques and procedures. As family

\footnotetext{
* I wish to thank the British Academy and the Royal Society of Edinburgh for funding visits to theatre archives and libraries in Italy to carry out research for this article.

${ }^{1}$ La Marchesa Colombi, Un matrimonio in provincia (Novara: Interlinea, 1999), pp. 30-31.
} 
and church have declined in importance as the central producers and regulators of "femininity", the fashion-beauty complex has grown. [...] Overtly, the fashion-beauty complex seeks to glorify the female body and to provide opportunities for narcissistic indulgence. More important than this is its covert aim, which is to depreciate woman's body and deal a blow to her narcissism. ${ }^{2}$

Bartky seems to be suggesting that the 'fashion-beauty complex' began to take root with the rise of liberalism and modernism in the late nineteenth-century. The emergence of women in the public sphere after Unification - as writers, educators, artists, and political activists - went hand in hand with a fundamental shift in perceptions of beauty in Italy with the growth of the 'fashion-beauty complex', which was promoted by the cosmetic industry and the advertizing of beauty products in women's journals. Whereas up until Unification beauty was tied to morality and virtue ${ }^{3}$ the main emphasis from the 1860 s onwards, following the rise of industrial capitalism, was now on artifice, ${ }^{4}$ and who better to promote this new conception of beauty than the by now ubiquitous figure of the modern-day diva, whose appearance was arguably implicit in her embodiment of the 'divine'. 5

Drawing on a wide selection of sources in the literary culture (theatre reviews; columns in women's journals; realist fiction), in this article I will show that men writers constructed the diva's 'beauty' as the salient and most important diva

\footnotetext{
${ }^{2}$ Sandra Lee Bartky, Femininity and Domination: Studies in the Phenomenology of Oppression (London and New York: Routledge, 1990), pp. 39-40. Bartky's italics. I am grateful to Danielle Hipkins for drawing my attention to Bartky's work.

${ }^{3}$ See Niccolò Tommasèo, Bellezza e civilità, o Delle arti del bello sensibile: studii (Florence: Felice Le Monnier, 1857).

${ }^{4}$ See Umberto Eco, Storia della bellezza (Milan: Bompiani, 2007), 340: 'È in quest'epoca [...] che Bellezza e Arte si fondono in una coppia inscindibile. Non vi è Bellezza che non sia opera di artificio; solo ciò che è artificiale può essere bello'.

${ }^{5}$ See Niccolò Tommasèo and Bernardo Bellini, Dizionario della lingua italiana (Turin: UTET, 1879), p. 916, whose entry on 'Bellezza' includes the definition 'Divina'.
} 
characteristic: for late nineteenth-century male critics, artists, and writers, whether a diva embodied the image of la bella italiana - she who, according to Stephen Gundle, 'had regular, though not necessarily classically perfect, features, long, simply-styled dark hair and expressive eyes ${ }^{\prime 6}$ - mattered very much: a diva's bellezza is without exception mentioned first and foremost in their reviews and novels. ${ }^{7}$ While Italian women writers also celebrate the diva's 'beauty', their reviews, columns in women's journals, and realist fiction reveal a concentration on her abilities as an artist over and above her aesthetic appeal. I will first examine the relationship between concepts of beauty and the rise of divadom from the beginning of women's emergence on stage in the sixteenth century. Though the period with which I am concerned in this article covers the birth of cinema, I will focus here on divas whose work consisted in performing live on stage. ${ }^{8}$ The diva's 'voice', in other words, her aural and physical bravura in live performance, for emerging female writers as spectators, served as a mode of, and metaphor for, female empowerment in a highly circumscribed, prescriptive, and conservative culture in the same way as it did for female theatregoers in the Anglo-American context. However, within Italy, as I shall demonstrate, there is evidence to suggest that the diva's (conscious, or otherwise)

\footnotetext{
${ }^{6}$ See Stephen Gundle, Bellissima: Feminine Beauty and the Idea of Italy (New Haven and London: Yale University Press, 2007), p. xvii. The image corresponds to how Paolo Mantegazza describes the 'Italian woman', though contrary to Gundle, Mantegazza makes regional distinctions: 'È fisicamente bella, se bruna; bellissima se agli occhi neri, alla pelle dorata dal sole, al labbro pubescente associa i capelli biondi. [...] Grassoccia e plastica e sensualmente molle e col nasino celtico in Lombardia, col biondo tizianesco e il pallore marmoreo in Venezia, di forme divine e scultorie a Bologna, quasi Latina ma più elastica della romana in Toscana, marmorea e imperiale a Roma, tremendamente greca a Napoli e Palermo; la donna italiana ci presenta quasi tutte le bellezze dell'Eva europea. [...] Piace immensamente agli uomini del Nord, che trovano in lei le virtù, che cercano invano nelle loro donne'. See Fisiologia della donna (Milan: Treves, 1893), pp. 182-83.

${ }^{7}$ Madame De Staël's Corinne from Corinne, ou L'Italie (1807), who is half Italian and a famous poetimproviser, is described as extremely beautiful. She embodies 'la bella italiana' with her 'cheveux du plus beau noir' and expressive eyes. Scrutiny of women's appearances was not solely limited to the diva: other women in the public sphere in Italy during this time were also subject to public scrutiny vis$\grave{a}$-vis their looks: the writer Matilde Serao was famously described as a hermaphrodite by Giovanni Verga. See his letter to Paolina Greppi, 21 February 1890 in Giovanni Verga, Lettere a Paolina, ed. by Gino Raya (Rome: Fermenti, 1980), p. 157.

${ }^{8}$ There are, of course, overlaps with cinema, and this article may offer foundations for work in this area.
} 
involvement in the 'fashion-beauty complex' was an integral component of spectators' admiration and pleasure in watching and hearing the diva; indeed, the particular preoccupation with 'beauty' and nationhood in modern Italian culture is poignantly articulated by the protagonist of D'Annunzio's Il fuoco (1898), who declares Italy as the mother of beauty. ${ }^{9}$

\section{Historical uses of the term 'diva'}

In order to contextualize this discussion, I wish to look briefly at the specific contextual and historical uses of the term 'diva' to refer to 'divine' women. Nowadays, the term mostly carries negative connotations to signify a woman who is regarded as temperamental or haughty, but in the medieval period 'divas' were venerated. My working premise in this article is that the phenomenon of the diva, whose nineteenth-century meaning was still 'dea', a 'female deity', ${ }^{10}$ is a male, Mediterranean construct; the diva, in the various historical, cultural, regional, geopolitical and social contexts in which she has been celebrated, is a product of western culture dating from the time of Classical Antiquity, though women have been deified as Goddesses for their beauty since the Egyptians. From Dante onwards, 'divine' women have been celebrated in Italian literature. ${ }^{11}$ The first recorded modern-day uses of the term, beyond the conventions of chivalry and medieval literature, were in Renaissance Italy during the revival of Antiquity, when saints were referred to not as

\footnotetext{
${ }^{9}$ Gabriele D’Annunzio, Il fuoco (Milan: Mondadori, 1963), p. 120: 'La fortuna d'Italia è inseparabile dalle sorti della Bellezza, cui ella è madre'.

${ }^{10}$ See Tommaséo and Bellini, Dizionario della lingua italiana, p. 338.

${ }^{11}$ See Dante, Par. IV, 118 where he invokes Beatrice as an 'amanza del primo Amante, o diva', and Petrach's Rerum vulgarium fragmenta 157, line 7: 'Facean dubbiar se mortal donna o diva fosse', though there were others in the lyric tradition who used the term to refer to women as divinities before Dante. See, for example, Panuccio dal Bagno's Rime in Lirici del secolo primo, cioè dal 1190 al 1300 (Venice: Giuseppe Antonelli Editore, 1839), p. 195: 'Della diva lor magna'.
} 
'Santus', but as 'Divus' or 'Deus', ${ }^{12}$ and 'divino', as an epithet for especially male artists, was pervasive. ${ }^{13}$ Specifically in the mid- to late-1500s, which witnessed the beginnings of the commedia dell'arte and the invention of opera in Italy, ${ }^{14}$ the first dive - such as the Venetian actress Vincenza Armani (1530-69), who was hailed as 'divina' by the commedia dell'arte actor Adriano Valerini Veronese - emerged. ${ }^{15}$ Several hundred years later, following the demise of the castrati, early nineteenthcentury Italian sonnets venerated the operatic prima donna. ${ }^{16}$ According to Susan Rutherford, the attrice cantante Giuditta Pasta (1797-1865) was the acknowledged 'diva del mondo' in the press between 1822 and $1836 .{ }^{17}$ The term circulated widely in late nineteenth-century Italian literary culture to refer not only to celebrated singers, but also to accomplished actresses, dancers, poet improvisers, and variety singers, hence my blanket usage of the term in this article to refer to female performing artists. The word 'divo' was also deployed in the media from the 1890 s as a synonym for a male actor or singer held in high regard. ${ }^{18}$ Yet, as I am arguing here, though the terms

\footnotetext{
${ }^{12}$ See Jacob Burckhardt, The Civilization of the Renaissance in Italy, translated by S. G. C. Middlemore, 1878 (Ontario: Batoche Books, 2001), p. 205; p. 413.

${ }^{13}$ See Patricia A. Emison, Creating the Divine Artist from Dante to Michelangelo (Leiden: Brill, 2004).

${ }^{14}$ The earliest opera is widely considered to be Jacopo Peri's Dafne, first performed in 1597, to a libretto by Ottavio Rinuccini. The new genre of entertainment was thought up by the Florentine Camerata, a group of humanists, musicians, poets, and intellecturals in late Renaissance Florence who gathered under the patronage of Count Giovanni de' Bardi to discuss and guide trends in the arts, especially music and drama. On the birth of opera, see David Kimbell, Italian Opera (Cambridge: Cambridge University Press, 1991), pp. 41-47. The commedia dell'arte is thought to have emerged in Rome in the 1550 s.

${ }^{15}$ See Oratione di Adriano Valerini veronese, in morte della divina signora Vincenza Armani, comica eccellentissima. Et alcune rime dell'istesso, e d'altri auttori, in lode della medesima. Con alquante leggiadre e belle compositioni di detta signora Vincenza (Verona, per Bastian dalle Donne, \& Giovanni fratelli, 1570). See also Rosalind Kerr, The Rise of the Diva on the Sixteenth-Century Commedia dell'Arte Stage (Toronto: University of Toronto Press, 2015).

${ }^{16}$ See Francesco Izzo, 'Divas and Sonnets: Poetry for Female Singers in Teatri arti e letteratura', in The Arts of the Prima Donna in the Long Nineteenth Century, eds Rachel Cowgill and Hilary Poriss (Oxford: Oxford University Press, 2012), pp. 3-20.

${ }^{17}$ Susan Rutherford, 'La cantante delle passioni': Giuditta Pasta and the idea of operatic performance', Cambridge Opera Journal 19:2 (2007), 107-38 (p. 108).

${ }^{18}$ According to Tullio De Mauro's Grande dizionario italiano dell'uso (Turin: UTET, 2000), p. 710, the term 'divo' to refer to a famous male performing artist was first used by Vittorio Pica. See Vittorio Pica, 'I cartelloni illustrate in Francia', in Il manifesto: arte e communicazioni nelle origini della pubblicità, ed. by Mariantonietta Picone Petrusa (Naples: Liguori Editore, 1994), pp. 30-45 (p. 39): 'Le dive, i divi e le divette del palcoscenico hanno, come è facile a comprendersi, molto spesso ispirato i
} 
'diva' and 'divo' were used widely in the periodical press during the late nineteenth century to refer respectively to female and male performing artists, they did not carry the same linguistic meaning. ${ }^{19}$ As becomes clear through a close reading of women's and theatre journals which contained reviews and profiles of performing artists, as well as a selection of realist fiction, to be a 'diva' in late nineteenth-century Italy entailed possessing 'beauty', whereas for the 'divo', attractiveness was secondary to his identity, and even superfluous. In male-authored journalism and in novels, men are generally 'faceless', while women are fetishized and receive greater attention for their physical attributes. Though the dominant view of dive was that they were morally questionable according to the social mores of the day, and that in exhibiting themselves on stage they indicated their fall from virtue, ${ }^{20}$ certainly in Italian literary culture they were nevertheless celebrated and lionized for their talents and looks. ${ }^{21}$ And yet, as Susan Leonardi and Rebecca A. Pope have shown in relation to AngloAmerican culture, the writers George Sand (1804-76) and George Eliot (1819-80)

disegnatori di cartelloni, che si sono assai compiaciuti nel riprodurne le fattezze caratteristiche ed $\mathrm{i}$ costume sfarzosi'. The article first appeared in the journal Emporium, 4:23 (November 1896), no page number. Writing on the singer Edoardo Garbin's performance in Bizet's Carmen in Genoa, the journalist Armando Mazza informs his readers that 'in quaresima poi il divo andrà al Regio di Torino'. See 'Ombre e riflessi' in Comoedia, January, February, March 1909 issue, p. 2. The singers Antonio Paoli (p. 6) and Alessandro Bonci (p. 7) are also referred to as divi.

${ }^{19} \mathrm{See}$, for example, articles in journals such as Cornelia; La donna; La voce della donna; Il giorno; Comoedia; Cordelia; Il mattino; La Rassegna degli interessi femminili; Cronaca dei teatri; La frusta teatrale; Il Marzocco.

${ }^{20}$ The nomenclature 'prima donna' was frequently used as a synonym for 'prostitute' during the nineteenth century, and in Italy the terms 'virtuosa' and 'prostituta' were almost interchangeable. See Benedetto Croce, I teatri di Napoli: Secolo XV-XVIII (Naples: Pierro, 1891), p. 372.

${ }^{21}$ I am not aware of any corresponding emphases on the diva's appearance in other European cultures or in North America during this time. Certainly from a reading of Susan Rutherford's chapter ' $L a$ Traviata or the "Willing Grisette": Male Critics and Female Performance in the 1850s', in Verdi 2001. Atti del convegno internazionale di studi, ed. by Fabrizio della Seta, Roberta Montemorra Marvin, and Marco Marica (Florence: Olschki, 2003), pp. 585-600, the reviews by male critics in Britain she draws on do not pay lip service to the divas' physical appearance. Similarly, in Gunilla Budde's chapter 'Between Nationalism and Cosmopolitanism: Female Opera Singers in Britain and Germany in the First Half of the Nineteenth Century', in Gender History in a Transnational Perspective, ed. by Oliver Janz and Daniel Schönpflug (New York: Berghahn Books, 2014), there is no mention of the notion of beauty being linked to dive in the German and English context. 
both challenge the notion of the prima donna as erotic siren in their writings. ${ }^{22}$ The same could be said of women authors writing on the diva in Italy at the fin de siècle. However, in contradistinction to their Anglo-American counterparts, and what is specific to the Italian context, is that women writers share with men writers a fascination with, and admiration for, the diva's 'beauty' and eroticism. Yet, as I will demonstrate in this article, this fascination manifested itself differently according to the writer's gender.

\section{Beauty and the diva}

The scrutinizing of women's bodies also has its roots in sixteenth-century Europe: the late fifteenth century saw a rise in portraiture paintings of women who were celebrated less for their social position and more for their physical beauty, and in the sixteenth century women's bodies were being scrutinized and objectified for their curves and complexion in the literary and visual culture for the first time. ${ }^{23}$ As we have seen, the period also saw the birth of another invention whose origins are Italian, that of opera, by the Florentine Camerata. Though the Council of Trent (1545-63)

\footnotetext{
22 See Susan J. Leonardi and Rebecca A. Pope, The Diva's Mouth: Body, Voice, Prima Donna Politics (New Brunswick, New Jersey: Rutgers University Press, 1996), p. 74: 'Divas in women's texts [...] tend to redress prima donna stereotypes and revise the representations of female singers we find in many texts by men, to recoup for women themselves the woman who has, in every sense of the word, a "voice". Sand, Eliot, and later women writers understood that the diva's "voice" could serve as both a mode of and metaphor for female empowerment in a culture that traditionally placed women on the side of silence. It is in this context that most women writers have placed their female singers and privileged the divas as the woman who has, preeminently and indisputably, gained a voice. The diva in this tradition is neither femme fatale nor happy handmaiden to what is finally a male muse. She is, rather, a hardworking woman more interested in music than marriage, in empowering women than seducing men. She garners the attention, admiration, and respect of the world with her singing voice, a voice that, after the era of the castrati, men cannot reach, usurp, or displace. Moreover, thanks to this singing voice she has a "voice" in the music she makes, in her own destiny, and in the larger world. Her privileged status as a female success in a male realm gives her license to probe, revise, and even reject the traditional gender code'. See also Susan Rutherford, The Prima Donna and Opera, 1815-1930 (Cambridge: Cambridge University Press, 2006), pp. 58-68. Rutherford also includes a discussion of fiction by Willa Cather (1873-1947).

${ }^{23}$ See Georges Vigarello, Storia della bellezza: il corpo e l'arte di abbellirsi dal Rinascimento a oggi, trans. by Maria L'Erario (Rome: Donzelli editore, 2007), p. 12: 'Esiste ovviamente una bellezza medievale: il viso simmetrico e bianco, il seno pronunciato, la vita stretta. I corpi evocati dalle parole del XVI secolo sembrano invece rivisitati: le carni vengono sottolineate, i termini si diversificano. Il corpo femminile, in particolare, acquista uno spessore e un colorito che prima non aveva'.
} 
reiterated St Paul's injunction, which forbade women to sing in church, and frowned upon women who performed on the public stage, there were bands of travelling musicians and actors which included professional women, and by 1600 every northern Italian court had a female singing group. ${ }^{24} \mathrm{~A}$ woman could aim for a professional career as a singer, commanding in some cases an exceptionally high salary, but she had to compete with the first operatic divinities: the castrati. ${ }^{25}$ John Rosselli's research on singers of Italian opera reveals that 'a woman singer in this period was at least as much looked at (and wondered at) as heard', and that 'women singers in the early days of opera [...] existed as objects of male expectancy, at once dubious and entrancing. They were not seen as straightforward professional musicians'. ${ }^{26}$ One commentator, writing in 1663 in Venice, reported that for a woman to be able to perform on stage she had to be above all 'beautiful', ${ }^{27}$ and a Rome-based singer, Luisa Sanches, who had applied for a Paris engagement, had listed her qualifications as 'her age (eighteen), her ability to play instruments and to sight-read, her looks and her morals (both good), her languages, and her memory'. ${ }^{28}$ Though Rosselli has argued that, thanks to the progress in the evolution of the musical language of opera seria in Naples, by the mid-eighteenth century public interest centred more on the capacity of the female voice to perform unheard of musical passages rather than on the appearance of the singer, ${ }^{29}$ similar 'beauty' characteristics were still required of turnof-the-century dive according to the director of the journal Cronaca dei Teatri, Emanuele Gaetani-Tamburini. Writing on the singer Linda Monti-Brunner, he said

\footnotetext{
${ }^{24}$ See Lucy Green, Music, Gender, Education (Cambridge: Cambridge University Press, 1997), p. 33.

${ }^{25}$ See Susan J. Leonardi and Rebecca A. Pope, The Diva's Mouth: Body, Voice, Prima Donna Politics (New Brunswick and New Jersey: Rutgers University Press, 1996), Chapter 1, pp. 24-47.

${ }^{26}$ See John Rosselli, Singers of Italian Opera: The History of a Profession (Cambridge: Cambridge University Press, 1992), pp. 58-59.

${ }^{27}$ See John Rosselli, 'From Princely Service to the Open Market: Singers of Italian Opera and their Patrons, 1600-1850', in Cambridge Opera Journal 1:1 (March 1989), 1-32 (n. 43, p. 12).

${ }^{28}$ Rosselli, Singers of Italian Opera, p. 58.

${ }^{29}$ Rosselli, pp. 58-59.
} 
that she 'possiede - in sommo grado - tutto ciò che è necessario per ottenere successi grandissimi in qualsiasi teatro: Voce bella, fresca, limpida, insinuante con acuti splendidi; modo eccellente di fraseggiare e gesto sobrio e vivace; figura attraente, fisonomia espressiva' ${ }^{30}$

'The beauty myth' - the idea that a woman's value is determined by how she looks, that female power comes from beauty - (as opposed to the 'fashion-beauty complex', which provides opportunities to women to embrace narcissistic indulgence only to depreciate women's bodies) thus began to percolate in the public imagination as more and more women took to the stage, and as women, as the subjects of paintings, started to be admired for their 'to-be-looked-at-ness'. ${ }^{31}$ This coincided with the beginnings of the Grand Tour (1660-1820), whence the idea of la bella italiana described by Gundle, emerged. ${ }^{32}$ As previously mentioned, the late eighteenth- and early nineteenth-centuries saw the demise of the castrati, and it was in the nineteenth century in Italy that female performing artists (as singers, actors, dancers and poet improvisers) became visible as never before in the popular imagination. One of the earliest Western theories of beauty, propounded by Aristotle, saw a relationship between beauty and virtue, arguing that 'Virtue aims at the beautiful'. ${ }^{33}$ In a return to these values during the nineteenth century, what was considered to be 'beautiful' by the Italian hegemony (priests, politicians, intellectuals) in nineteenth and early twentieth-century Italy extended beyond a woman's looks to appraise the virtue and

\footnotetext{
${ }^{30}$ Emanuele Gaetani-Tamburini, 'Linda Monti-Brunner: la sua carriera, i suoi trionfi, le sue interpretazioni', Cronaca dei Teatri, 15 December 1905, no page number.

${ }^{31}$ I borrow the phrase 'the beauty myth' from Naomi Woolf's book The Beauty Myth: How Images of Beauty are Used Against Women (New York: Morrow, 1991). For recent work on 'the beauty myth' in western culture, see Carla Rice, Becoming Women: The Embodied Self in Image Culture (Toronto: University of Toronto Press, 2014). On women's 'to-be-looked-at-ness', see Laura Mulvey's classic essay, 'Visual Pleasure and Narrative Cinema', Screen 16:3 (Autumn 1975), 6-18.

${ }^{32}$ Stephen Gundle, "'Venus on Earth": Lina Cavalieri and the Professionalisation of Italian Beauty between the fin de siècle and the Belle Époque', Italian Studies 62:1 (Spring 2007), 45-60 (p. 45).

${ }^{33}$ See Ronna Burger, Aristotle's Dialogue with Socrates: on the Nicomachean Ethics (Chicago; London: University of Chicago Press, 2008).
} 
submissiveness of her character. ${ }^{34}$ Niccolò Tommasèo wrote in 1857 of beauty: 'La bellezza che non insegna virtù, o la insegna meno potentemente, sia sempre da voi posposta, ${ }^{35}$ and later on in the century even the first female emancipationists associated beauty with virtue. Writing to her friend Gualberta Adelaide Beccari in her emancipationist journal La donna in 1868, Leonia Cinotti called upon its female readers to contribute articles on 'letteratura, arti, politica, storia, teatro, critica, scherzo', arguing that 'tutto infine è a nostra portata, che tutto provi all'uomo che, se gli antichi erigevano tempii alla sola Bellezza, oggi essi con più ragione possono erigerne alla donna, perchè essa personifica Bellezza, Scienza e Virtù' ${ }^{36}$ In the early twentieth century, writing in 1911, Prof. Arnaldo Salustri defined beauty as 'salute, regolarità di forme, grazia di movenze, bontà, contentezza, equilibrio', ${ }^{37}$ and anthropologist Paolo Mantegazza warned women against using make-up, suggesting it was poisonous: 'I poveri artisti drammatici, che sono costretti forzatamente a far uso dei belletti, che spesso contengono piombo, soffrono di cefalea, di dolori reumatici, di paralisi e d'altri malanni ad un lento avvelenamento'. ${ }^{38}$ The 1890 s was a time in which criminal positivist anthropologist Cesare Lombroso was arguing that women were morally, intellectually, and sexually inferior to men, and that whether or not a woman was a delinquent could be determined by the shape or her skull and her physiognomy. He singled out ugly women as the cruelest: 'È triste ma vero: la femmina, tra i bruti [sic.], i selvaggi ed i popoli primitivi, è più crudele che pietosa,

\footnotetext{
${ }^{34}$ On the Italian tragic opera stage, the feminine ideal, embodied in the suffering heroine's foil (Alfredo's sister in Verdi's La Traviata; La Marchesa Attavanti in Puccini's Tosca), was a constant reminder to the female public of 'proper' behaviour as good wives and mothers.

${ }^{35}$ Tommasèo, Bellezza e civiltà, p. 2.

${ }^{36}$ La donna, 31 May 1868, p. 30. Cinotti’s italics.

${ }^{37}$ Arnaldo Salustri, La bellezza femminile: libro per la bella gioventù femminile, per le madri, per le maestre (Sacile: Luigi Ongania Libraio Editore, 1911), preface (my italics).

${ }^{38}$ Paolo Mantegazza, Dizionario d'igiene per le famiglie (Sesto S. Giovanni: Casa Editrice Madella, 1911), p. 317.
} 
per quanto meno crudele del maschio'. ${ }^{39}$ It was also the start of the age of mass communication, a period that witnessed the development of the modern press, photographic reproduction, international theatre circuits, and advertizing; arguably, these changes towards a capitalistic, image-saturated culture marked the arrival of Bartky's 'fashion-beauty complex'. Late nineteenth-century female performing artists were society "'beauties" who "were coming to represent a new kind of femininity that was closely tied to the mass production of images [and] was thus strongly identified with fashion and consumption', ${ }^{40}$ and, as Gundle has remarked, the period saw professional performers take over a heritage of ideas of beauty that had until then been almost solely pictorial and literary. ${ }^{41}$ Postcards of dive and divi were in increasingly wide circulation, and bore witness to performing artists' allure. They served a phatic role, creating a network of social interrelationships that cut across boundaries of class and race, breaking down perceived hierarchies of star-audience relations. $^{42}$ Images of dive and divi in the advertizing of beauty products similarly addressed these hierarchies. In the women's journal La donna (not to be confused with Beccari's emancipationist journal of the same name) in 1909, colluding with the 'fashion-beauty complex', the opera singer Celestina Boninsegna (1877-1947) advertised a product that prevented hair loss. A photograph of the diva is the centrepiece of the advert, which includes a handwritten statement of her endorsement

\footnotetext{
${ }^{39}$ See Cesare Lombroso and G. Ferrero, La donna delinquente, la prostituta e la donna normale (Turin: Fratelli Bocca, 1892), $4^{\text {th }}$ edition, p. 55. First edition 1891.

${ }^{40}$ Erika Diane Rappaport, Shopping for Pleasure: Women in the Making of London's West End (Princeton: Princeton University Press, 2000), p. 185.

${ }^{41}$ Gundle, "“Venus on Earth", 46.

${ }^{42}$ The term 'phatic communication' is verbal or non-verbal communication that has a social function. It was coined by Bronislaw Malinowski in the early 1900s. See Malinowski, 'The Problem of Meaning in Primitive Languages', in Charles Kay Ogden and Ivor Armstrong Richards, The Meaning of Meaning: A Study of the Influence of Language upon Thought and of the Science of Symbolism (London: Kegan Paul, Trench, Trubner \& Co., Ltd., 1923), Supplement I., pp. 451-510.
} 
of the product. ${ }^{43}$ [Figure [1] - ALSO OF ROSINA STORCHIO Figure [2]] Similarly, in the April 1909 issue, among the adverts for corsets, anti-wrinkle, and breastenhancing creams, the names of the dive Dina Galli (1877-1951), Lina Cavalieri (1874-1944), Irma Grammatica (1867-1962), and Eleonora Duse (1858-1924) are mentioned in association with an advert for a particular perfume. Though the advert does not include a photograph of these particular dive, their caricatures are drawn by the cartoonist Enrico Sacchetti (1877-1967), breaking with the stereotype of the hallowed, otherworldly diva to popularize it and send it up. ${ }^{44}$ Figure [3]

Dive and female spectators were all too aware of the requirement to be 'beautiful'. Writing in 'La Rassegna degli interessi femminili' in 1887, an author with the pseudonym Veritas lamented that 'molte delle dive delle operette e dei vaudevilles, debbono il loro posto più ai begli occhi, che al canto', ${ }^{45}$ and the fictional dive protagonists from Annie Vivanti’s Marion, artista di caffe-concerto (1891) and D’Annunzio's Il fuoco (1900) are both acutely aware of beauty being a requirement of Italian divahood. ${ }^{46}$ Late nineteenth-century dive exercised shaping, even defining, roles, yet as Gundle has argued in relation to Lina Cavalieri (1874-1944), divas in the late nineteenth-century Italian context were also trapped in the discourse of beauty, 'enmeshed in the mass reproduction, distribution and consumption of female

\footnotetext{
${ }^{43}$ La donna (rivista quindicinale illustrata), 5 March 1909, p. 2. Boninsegna's handwritten statement of 14 August 1907 reads: 'Sono lieta dichiarare che in seguito all'uso della Chinina Migone la mia capigliatura si è resa folta lucida e morbida; non solo continuerò ad addoperarla, ma la raccomanderò alle mie compagne d'arte certa di acquistarmi la loro riconoscenza. Celestina Boninsegna'. Another celebrated opera singer, Rosina Storchio (1876-1945), advertised the same product the following month.

${ }^{44}$ La donna, 5 April 1909, p. 44.

${ }^{45}$ La rassegna degli interessi femminili, 15 January 1887, p. 307.

${ }^{46}$ See Annie Vivanti, Marion, artista di caffè-concerto (Palermo: Sellerio editore, 2006), and D'Annunzio's Il fuoco. Foscarina, the female protagonist of D'Annunzio's novel, is plagued throughout the novel by her waning beauty as she compares herself to the more youthful diva whom she knows her lover, Stelio, desires, and Marion in Vivanti's novel takes pity on her less attractive colleague, Gina, who wishes to be released from her contract (p. 41).
} 
imagery' ${ }^{47}$ In the literary culture, too, dive are generally valued more by male writers for their appearance than for their work. Women writers also celebrate the beauty of the diva, as well as that of the divo. Nevertheless, their emphasis above all on the diva's talents and accomplishments as professional artists can be seen as evidence of a celebration of female performance and empowerment within an androcentric and misogynist societal framework that locked women, and sometimes men, in 'the beauty myth'.

\section{Italian beauty and divahood in the press}

From my reading of a selection of women's journals, theatre journals, and realist fiction in fin de siècle Italy, I have come across merely two references to the physical appearance of the divo, penned by an anonymous journalist writing in La Frusta teatrale in 1862. In both references the male singers' voices are commented upon first; their physical appearance is of secondary importance to the author (and, presumably, his readers). Describing Luigi Colonnesi's performance in the role of Monteforte in Verdi's I vespri siciliani in Turin in 1862, the journalist observes that 'la sua voce è sempre colossale come la sua figura'. ${ }^{48}$ A similar example of a privileging of the divo's professional skills over and above his physical appearance is demonstrated by the same unknown journalist who remarks on the tenor Armandi's performance of Masaniello Daniel Auber's La muta di Portici (first performed in 1828) at the San Carlo in Naples:

Egli ha bella voce, canta bene, ed è degno delle grandi scene di S. Carlo, specialmente perchè accoppia la rara qualità di un perfetto

\footnotetext{
${ }^{47}$ Gundle, "VVenus on Earth", p. 60.

${ }^{48}$ La frusta teatrale (giornale letterario, artistico teatrale), 30 dicembre 1862. No page number.
} 
attore. La sua figura bellissima, il sentimento profondo, l'azione grandiosa e sentita, l'hanno renduto un Masaniello perfetto da trarre gridi sino al volersi il bis di qualche pezzo in mezzo a fragorosi applausi. ${ }^{49}$

The requirement of 'un perfetto attore' to possess a 'figura bellissima' suggests that divi, too, were expected on some level to conform to standards set by 'the beauty myth'. Mention of a divo's physical appearance in the literary culture is rare, though desiring women journalists also occasionally commented on male beauty. Writing in Beccari's La donna in 1881, an author with the pseudonym Flora describes the grande attore Tommaso Salvini (1829-1915) as 'un bell'uomo', ${ }^{50}$ and the writer Ida Baccini (1850-1911) defines the composer Pietro Mascagni (1863-1945) in her Cordelia as 'peggio che bello', admiring his 'fisonomia molto fine, d'una eccessiva mobilità; una fisonomia di ragazzo scapato, a cui l'inconsapevole [...] negligenza della bruna capigliatura e il lampo vivo dei dolci occhi pensosi, danno una impronta speciale, caratteristica'. ${ }^{51}$ There is an entry in the journal Cornelia in 1876 by a writer with the pseudonym 'Fosfero', who writes a 'Rivista teatrale'. S/he(?) describes the actor Ernesto Rossi (1827-96) as 'un grande artista, ed un bell'artista'. ${ }^{52}$ Here the writer comments first on Rossi's qualities as an actor before mentioning his physical appearance, as in the previous examples (suggesting the author is male), yet, in an intriguing role reversal, Flora passes comment first on Salvini's appearance before proceeding to list his qualities as an artist, and Baccini makes no excuses for writing solely about Mascagni the person, declaring 'Io non vi farò della critica musicale... Io... vi parlerò un po’ del Mascagni uomo, del Mascagni giovinotto, che pochi

\footnotetext{
${ }^{49}$ La frusta teatrale.

${ }^{50}$ See 'Da Firenze. La lettura di Tommaso Salvini al Circolo Filologico' in La donna, 30 November 1881, pp. 40-42.

${ }^{51}$ Cordelia (Rivista letteraria educativa dedicata principalmente agli interessi morali e materiali delle donne italiane), 27 November 1892, p. 20.

${ }^{52}$ Cornelia, 1 November 1876, p. 183.
} 
osservano, che pochissimi studiano' ${ }^{53}$ In contrast, the majority of reviews and artist profiles written by women among the selected sample emphasize first and foremost the diva's talents as a performer. Writing in her column 'Api, Mosconi e Vespe' in her daily newspaper Il mattino on the musician Maria Felicità Tua, Contessa FranchiVerney della Valletta, alias Teresina Tua (1866-1956), Matilde Serao describes the 'magia del suo ingegno di violinista, col suo sorriso scintillante di creatura beata dell'arte, col suo buono sguardo dolce e vivido, ${ }^{54}$ and in a published letter written by Adele Chiminello to her friend Beccari in 1877 on the actress Giacinta Pezzana Gualtieri's performance in Luigi Gualtieri’s La Signora di Rimini at the Teatro Rossini, Chiminello writes 'La signora Pezzana fu applaudita entusiasticamente: lo sarebbe stata di più, se l'emozione non avesse strozzato la voce a molti... alle donne almeno, lo assicuro. Era bella nel suo candido abito di vergine e di sposa; ma divinamente bella all'ultimo atto, nella sua nera veste di velluto, e cinta il seno ed il capo leggiadro di candidi veli, soffusa di mestizia e pallore'. ${ }^{55}$ The mention here that the women in the audience in particular were bowled over by Pezzana to the extent that she took their breath away is intriguing. These accounts bear witness above all to women's celebration of the divas' performances and talents, while their physical attributes and clothes are mentioned secondarily. An anonymous writer for the women's journal Cornelia, reviewing a performance of Ambroise Thomas's Mignon at the Pergola in Florence in 1876 says 'La signora Maria Durand, Americana, sostiene la parte della protagonista. Questa signora è una cantante dotata di mezzi e di talento non comune. Essa ha espressione, accento drammatico, colorito, metodo, voce

\footnotetext{
${ }^{53}$ Ida Baccini, 'Pietro Mascagni', Cordelia, 27 November 1892, p. 20.

${ }^{54}$ Il mattino, 23-24 March 1892, p. 1.

${ }^{55}$ La donna, 30 January 1877, p. 2681.
} 
potentissima, bella figura ..., ${ }^{56}$ There is also evidence that women celebrate, and find pleasure in the diva's beauty. Neera, writing on Eleonora Duse's appearance in $\mathrm{Il}$ Marzocco in 1901, having ascertained from a Neapolitan male colleague that Duse is 'beautiful', 'quantunque la sua bellezza fragile e delicata non sembri di quelle destinate a ricevere risalto dal palcoscenico' (meaning, perhaps, that she does not conform to contemporary notions of la bella italiana), and that the journalist, Leone Fortis (1824-1896), candidly says of her 'Non è bella', declares, 'io voglio proclamare alta e forte la bellezza del suo sorriso'. ${ }^{57}$ Similarly, writing in her newspaper Il giorno in 1916, Serao comments on 'la vezzosa e fine cantatrice Nera Marmora'; 'la deliziosa, incantevole creatura di sogno, Ettorina Mazzucchelli, lieve come un soffio d'ali, in una notte stellata, ombra fugace di farfalle in un raggio di luna!'; 'Maria Melato, copressione di profondità e di grazia' ${ }^{58}$

Conversely, men writers' accounts of divas privilege their looks over their artistic talent. The aforementioned journalist Mazza, writing in Comoedia, mentions that 'Bianca Masnata, la giovane soprano bella e intelligente, a Trieste ha riportato veri trionfi in Wally, ${ }^{59}$ His profile of the Russian soprano Nadina Legat (1889 - ?) goes into great detail on her appearance:

'La sua bellezza è tutta qui: nel fascino del suo sorriso, nell'arco vermiglio delle gengive, nella chiostra dei denti perlati, negli occhi corruscanti morati come il frutto del rovo, nel casco degli ondulati

\footnotetext{
${ }^{56}$ Cornelia (Rivista letteraria educativa dedicata principalmente agli interessi morali e materiali delle donne italiane), 16 February 1876, p. 47.

${ }^{57}$ Il Marzocco, 'Il sorriso della Duse', 24 March 1901, p. 1.

${ }^{58}$ Il giorno, 'In un teatro, tutti i teatri', 9 January 1916. Serao also purportedly described Lina Cavalieri as an embodiment of beauty, referring to her 'visino di Madonna apocrifa' which had a 'linea di purezza e di una grazia adorabile', while her bust had 'lo sboccio di uno stelo, e i suoi occhi un languore fra di tristezza e di réverie'. Cited in Vittorio Paliotti, Il Salone Margherita e la belle époque (Rome: Benincasa, 1975), p. 193.

${ }^{59}$ Comoedia, 'Ombre e riflessi', January, February, March issue 1909, p. 2.
} 
capelli corvine, e in fine in tutta la morbida linea del corpo che si snoda in una spira serpentina, accendendo nell'anima nostra tutti i desideri, tutti i sogni dell'ebrezza e ogni incantamento. È per questo che noi oggi la salutiamo con la commossa voce del giubilo; per la sua bellezza maliosa e per la giovane sua arte già trionfante' ${ }^{60}$

The diva Bella Gorsky is reported in Cronaca dei teatri as having 'nel volto, bellissimo, il sorriso della primavera dolce...Ed ora, la bellissima artista si presenterà, nei nostri teatri, a raccogliere nuovi applause', ${ }^{61}$ while the Milanese journal La frusta teatrale reports on La Spezia's performance in Palermo declaring she is 'una delle più belle, care e simpatiche Traviate dell'epoca'. ${ }^{62}$

\section{Fictional discourses of 'beautiful' divas}

I will now argue a similar trend in narrative fiction whereby women writers describe dive as hardworking, talented women and male writers privilege the 'beauty' of the diva over her artistic talents. I shall focus on the inherently descriptive genre of realist fiction, in particular Verga's Eva (1873), La Marchesa Colombi’s ‘Teste Alate’ (1879), Annie Vivanti’s Marion: artista del caffè-concerto (1891), Verga's 'La serata della diva' (1894), and D'Annunzio's Il fuoco (1900). ${ }^{63}$ As with the journalism, what emerges clearly from a close reading of the aforementioned titles is an emphasis on, and celebration of, the diva's 'beauty'. In Verga's 'La serata della diva', the actress

\footnotetext{
${ }^{60}$ Comoedia, 'Ombre e riflessi', January, February, March issue 1909, p. 3. A similarly positivist approach is used to describe the diva Rosalia Garitano: 'È una donna seducente e una cantante di valore. .... e la bellezza fisica, manifestantesi nella linea perfetta delle sue forme procaci ed armoniose e nel fulgore delle sue pupille, e l'ardenza dell'anima fascino alla sua bellezza ed ella, commossa, ringraziava il pubblico plaudente, il quale non era mai stanco di evocarla fra una pioggia di fiori e fra grida di evviva', p. 8.

${ }^{61}$ Cronaca dei teatri, 15 February 1905. Author unknown. No page number.

${ }^{62}$ La frusta teatrale, 'Teatri italiani', 30 December 1862 . Author unknown. No page number.

${ }^{63}$ The latter two texts were both inspired by the 'grande attrice' Duse.
} 
Celeste is described as 'La bella'; ${ }^{64}$ in Vivanti's Marion the eponymous protagonist is celebrated as a 'bella creatura'; ${ }^{65}$ the male protagonist of Verga's Eva presents the ballerina as 'splendente di bellezza'; ${ }^{66}$ the actress Vittoria and her sister in La Marchesa Colombi's 'Teste alate' are 'due belle teste di donne', ${ }^{67}$ and in D’Annunzio's novel, actress, singer and dancer are 'le tre donne dionisiache' ${ }^{68}$ In a country in which there has been a long-established tradition of beauty worship, both women and men writers acknowledge divas' beauty. Indeed, both women and men writers pass comment, via their respective narrators, on the divas' lack of virtue. However, whereas in the men's fiction this is presented as toxic - both the singer Donna Arvale and the actress Foscarina are described as 'tentatrici' in D'Annunzio's novel, and Eva 'attossicava con la gelosia' the male protagonist of Verga's story ${ }^{69}$. an element of regret concerning the divas' loss of virtue pervades the women's fiction. In Vivanti's Marion, commenting on the 'occhi cerchiati di nero' of one caféconcerto singer, a friend explains them as connoting the 'irreparabile perdita della [sua] virtù', and in La Marchesa Colombi's short story the actress Vittoria expresses remorse at her realization that in early post-Unification Italy, being a respectable wife and actress are, in fact, mutually exclusive. ${ }^{70}$ Moreover, whereas the men's fiction presents dive as rivals, the women writers' narratives portray them as allies and as expressing solidarity. 'La diva del canto' of Verga's 'La serata della diva'

\footnotetext{
${ }^{64}$ Giovanni Verga, 'La serata della diva', in Tutte le novelle, with an introduction by Carla Riccardi (Milan: Mondadori, 1979), pp. 753-65 (p. 763).

${ }^{65}$ Vivanti, Marion, p. 67.

${ }^{66}$ Giovanni Verga, Una peccatrice; Storia di una capinera; Eva; Tigre Reale (Milan: Mondadori, 1973), pp. 251-343 (268).

${ }^{67}$ La Marchesa Colombi, 'Teste alate' in Serate d'inverno (Ferrara: Luciana Tufani Editrice, 1997), pp. 61-92 (64).

${ }^{68}$ D’Annunzio, Il fuoco, p. 118.

${ }^{69}$ Verga, Eva, p. 326: 'Sirena! maliarda! che mi aveva inebbriato coll'amore, ed ora mi attossicava con la gelosia!' See also D’Annunzio, Il fuoco, p. 87.

${ }^{70}$ Vivanti, Marion, p. 37, and La Marchesa Colombi, 'Teste alate', p. 81: 'L'avevo sposato unicamente nell'idea fissa di mostrare alla gente, che mi aveva disprezzata, che si può essere una attrice, ed essere onesta come un'altra fanciulla e fare un bel matrimonio, e rimanere una buona artista diventando una gran dama, ed una buona moglie. Era stata un'illusione'.
} 
'[scambiava] ... un'occhiata ostile coll'altra diva della danza', ${ }^{71}$ and in D'Annunzio's novel the omniscient narrator informs us of Foscarina's jealousy of the younger, and more beautiful, Donna Arvale. ${ }^{72}$ In contrast, Vivanti's Marion presents a case of female solidarity when the eponymous protagonist, upon learning of Gina's unhappiness in the profession, allows herself to be kissed on the mouth by her boss in exchange for the release of her colleague from her contract. ${ }^{73}$ Similarly, in La Marchesa Colombi's short story the actress, Vittoria, is described as admiring other actresses. ${ }^{74}$ This aspect of female solidarity among dive was present also among women in the public sphere as writers and political activists in late nineteenth-century Italy. ${ }^{75}$ In addition, dive in women's fiction are presented as having earning power and successful careers. Marion is financially independent in Vivanti's novel, and reference is also made to a ballerina who finances a certain Carelli. ${ }^{76}$ In La Marchesa Colombi's short story 'Teste Alate', Vittoria mentions certain newspaper articles that comment on her success as an artist. ${ }^{77}$

\section{Conclusion}

If, as this article suggests, it was indeed the case that to be a diva in late nineteenthcentury Italy, having 'feminine beauty', or what Catherine Hakim has recently dubbed 'erotic capital' ${ }^{78}$ was a requirement, dive may well have consciously participated in Bartky's 'fashion-beauty complex', promoting and managing their careers and

\footnotetext{
${ }^{71}$ Verga, 'La serata della diva', pp. 753-65 (p. 764).

${ }^{72}$ D'Annunzio, Il fuoco, p. 235 : '[Foscarina] sentì tutto l'orrore della rivalità palese tra l'amante non più giovine e la fanciulla che è forte della sua giovinezza intatta'.

${ }^{73}$ Vivanti, Marion, p. 41.

${ }^{74}$ La Marchesa Colombi, 'Teste alate', p. 77: 'Si esaltava per l'arte, si entusiasmava d'un autore, d'un attore, anche d'un attrice'.

${ }^{75}$ See Katharine Mitchell, "“Sorelle in arte (e politica?)"”: The "woman question" and Female Solidarity at the fin de siècle', in Women and Gender in Post-Unification Italy: Between Private and Public Spheres, ed. by Katharine Mitchell and Helena Sanson (Oxford: Peter Lang, 2013), pp. 197-224.

${ }^{76}$ Vivanti, Marion, p. 87: 'Carelli, che s'era rovinato per pagare i debiti di suo fratello morto pazzo, e che ora si faceva mantenere da una vecchia ballerina'.

${ }^{77}$ La Marchesa Colombi, 'Teste alate', p. 79.

${ }^{78}$ See Catherine Hakim, Honey Money: the Power of Erotic Capital (London: Allen Lane, 2011).
} 
reputations as image-makers and self-commodifiers. And yet, like the women writers who presented dive in women's journals and fiction, and keen to be valued above all for her art, upon receiving a request for her biography from a journalist working for the Venetian newspaper Tempo, Duse refused to provide details. Instead, she responded: 'Se prima che io fossi attrice nessuno s'interessava di me, perchè oggi l'artista dovrebbe svelare la donna? Non mi credo obbligata a questo, e non lo faro mai... e per finirla dichiaro, che di tutte le biografie scritte sul mio conto, nessuna è esatta - tutte sono indiscrete. E a fine e a base di tutto questo, ricercate e giudicate la sola manifestazione di me che vi appartiene - quella dell'arte... il resto non appartiene a nessuno, e mi firmo' ${ }^{79}$

If the diva 'serves as a microcosm of cultural attitudes towards women more generally, of a fundamentally misogynist response to female ambition and success', 80 the beauty double-standards operating at the turn-of-the-century for performing artists in Italy were likely being applied also to ordinary citizens. We can suppose that they were if - assuming that realist fiction describes the 'extratextual' world in a 'faithful' way $^{81}$ - we recall Denza's delight at being informed of her 'beauty' in La Marchesa Colombi's domestic novel mentioned at the beginning of this article. By championing the diva's skills as a performer and artist, women writers' accounts of divas in late nineteenth-century Italy were fashioning a less one-dimensional image of the Italian

\footnotetext{
${ }^{79}$ The letter was re-printed in the column 'Spigolando' by 'La Spigolatrice' in Beccari's emancipationist journal La donna on 20 August 1885, p. 345.

${ }^{80}$ Melissa Bradshaw, "Devouring the Diva: Martyrdom as Feminist Backlash in The Rose," Camera Obscura, 67, 23:1 (Spring 2008), 69-87 (p. 71).

${ }^{81}$ Ankersmit's definition of the properties of realist fiction - which I endorse - is as follows: '[Realist fiction] gives copious information about various periods, regions, and social strata; it emphasizes the unexpected, the contingent, and the factual ("chosisme"); it favours referentiality; man is seen as a product of his heredity and of his historical and social environment; the emphasis is on the typical rather than the exceptional, encyclopaedic; time exposition is extremely well-documented and informative, and demonstrates a painful awareness of the writer's subjectivity; a judicious rationing of facts is strived for, the mentality is sceptical; the plot is even-paced and non-dramatic; a dry and direct, transparent style is used, resulting in a "hurried" prose that has no patience with superfluous matter; and, lastly, the intentions are didactic'. See Frank R. Ankersmit, History and Tropology: The Rise and Fall of Metaphor (Berkeley, CA: University of California Press, 1994), p. 142.
} 
diva. Far from being the worshiped yet reviled and ridiculed femme fatale from male literary representations, for middle-class Italian women writers, dive at the end of the nineteenth century were authentic, fabulous, ambitious, successful, and inspirational performing artists who, to ordinary middle-class women in the audience, represented a promise, however illusory, of being valued on equal terms with men. 